\title{
The Celebrity Family Endorsement on Instagram Product Advertisement (Case: The Hermansyah)
}

\author{
Sakti Hendra Pramudya \\ Faculty Member, Department of Management-BINUS Online Learning, \\ Universitas Bina Nusantara (Indonesia) \\ PhD Candidate, Faculty of Business and Economics, University of Pécs \\ (Hungary) \\ sakti.pramudya@binus.ac.id*
}

\begin{abstract}
The main purpose of this study is to analyze the consumer's perception of celebrity family endorsement in the context of Instagram advertisement. The object of this research is The Hermansyah (Anang Hermansyah family brand). This paper comprises of two separate studies: (1) The first study would use a 2 x 2 factorial design to compare the Instagram user's response towards four stimuli of Instagram advertisements. Two stimuli would depict the Instagram advertisement of a single celebrity endorser and the other two stimuli would depict celebrity family endorser for acne cream product and cake product. (2) The second study is a consumer's opinion survey about the advertisements. Based on the survey results of 547 The Hermansyah Instagram followers, it is revealed that celebrity family endorsement for cake products could trigger the respondent's desire to purchase the product than a single celebrity endorsement. On the other hand, the celebrity family endorsement for acne cream product captivates respondent's attention as well as triggering the intention to search for more information about the product. Hence, it can be concluded that the consumer engagement of celebrity family endorsement only exists in the initial stage (attention) and middle stage (desire and search) of consumer's psychological process to purchase a new product.
\end{abstract}

Keywords: Celebrity, Celebrity Family, Endorsement, Instagram.

\section{Introduction}

The family business is unique. The existence and the involvement of family members in this business organization have created unique characteristic which differentiates from non-family businesses entities. Prior findings in various research have indicated that consumers perceive family business firms positively. The consumer tends to perceive family business as a business that possesses great craftsmanship that is inherited from generation to generation, strong social bond with the community, fairly treated their employees, and trustworthy (Krappe, Goutas, \& Von Schlippe, 2011; Beck \& Kenning, 2015). The family business identity could be considered as 'sacred asset' which differentiate them from other business organization and even from other product. The avenue to utilize family business identity for product marketing purposes is widely open. Micelotta and Raynard (2011) described that the family business firm identity is essential in achieving a competitive advantage from competitors and it can be achieved by utilizing branding strategies with a strong emphasis on promoting family business brand identity. This family brand identity is a 'message' that being delivered to the consumer. After received by the consumer, this 'message' will be transformed into 
an image in the consumer's memory (Keller, 2003). Thus, it is essential to preserve the reputation of the family business to avoid negative association towards the firm's brand identity which would affect the image in the consumer's mind.

Preserving the reputation of a brand also important in the context of the human brand. The human brand is a term that refers to any famous persona who becomes the subject of marketing communication (Rindova, Pollock, \& Hayward, 2006). From the marketing perspective, a brand may relevant to a product, firm, and service. Nevertheless, celebrities could also be considered as brands due to they could be managed professionally and they also possess additional associations and features of a brand (Thomson, 2006). The human brand identities vend product brands via endorsements and persuasions by providing personality qualities to inanimate brands while encouraging consumption (Holmes \& Redmond, 2014). Thus, as the human brand, when the endorser possesses positive publicity, the consumer would perceive the brand in a positive way.

If the elements of celebrity endorsement are combined with family business branding strategy, a new and unique marketing strategy would emerge, namely the celebrity family branding. Parmentier (2011) has presented the aforementioned strategy very well by examining the practice of the David and Victoria Beckhams (The Beckhams) family brand. This family brand is created by the merging of both David and Victoria's respective individual person brands and their branding method has been proven successful in the market. However, further analysis needs to be taken to determine whether consumers are truly interested in the family brand or toward the individual celebrity instead. This analysis is necessary due to other research findings demonstrate that strong attachment exists between consumers and a specific celebrity individual regardless of the number of endorsers (Hsu \& McDonald, 2002) or endorsements (Ilicic \& Webster, 2011). The problem would lead to the main research question in this study; does the consumer value celebrity family endorsement more than individual or single celebrity endorsement?

Moreover, the trend of social media marketing has captivated the attention of marketing experts since it has been praised for its effectiveness in reaching consumers with very minimum cost (Evans, 2010). One of the widely used social media applications perfectly utilized by marketers to market their product is Instagram (Djafarova \& Bowes, 2020). Instagram is the fastest-growing online photo and video sharing application in which users could share their images from their daily life with other users, nevertheless, the academics research which discusses this social media, especially in the context of digital marketing, is scarce (Sheldon \& Bryant, 2016). Nonetheless, currently, there are abundant Instagram users which utilize this social media as a digital platform to advertise their product. The advertisement varies in categories ranging from an online shopping account which advertise a non-branded product by using simple product photos, to a professional branded product account which published tailor-made photos and videos for the promotional purpose (Djafarova \& Bowes, 2020). In the context of Indonesia itself, Instagram has become the 4th most used social media platform after Youtube, Facebook, and Whatsapp as of 2019 (Kemp, 2020). Adi and Hidayat (2018) also mentioned in 2018 that the total number of Instagram users in Indonesia reached 45 million users with a growing trend. The majority of the active Instagram users in Indonesia are coming from generation $\mathrm{Y}$ which, interestingly, exhibit 
impulsive buying patterns (Aprilia \& Setiadi, 2017) and hedonism (Utari \& Rumyeni, 2017). The product marketers in Indonesia apparently aware of this situation and utilize Instagram to promote their products and services (Verawati, 2016). According to the previous research, there are shreds of evidence that Indonesian celebrities are depicting their familial value as part of their personal branding as well as for the product endorsement (Rizal, 2019; Tandera, 2018). However, there is no evidence of previous research which measure the consumer's perception of depicting the familial value of Indonesian celebrities in the celebrities' social media account for product endorsement purpose. This premise would lead to the first research question of this study: What is the general perception of Indonesian consumer towards product endorsement which depicts the familial value of the celebrity?

\section{Theoretical Framework}

\subsection{Family Business Branding and Celebrity Family Brand}

The grand theory of this research is coming from two perspectives: branding and celebrity. According to branding theory, a brand is a repository of meanings that supported by a combination of intentions to market the product or services, consumer interpretations, and various associations of socio-cultural networks (Diamond, Sherry, Muniz, McGrath, Kozinets, \&, Borghini, 2009; Sherry, 2005). The interpretation and association of socio-cultural networks are in-turn closely associated with the concept of celebrity in terms of its visibility and distinctiveness (Parmentier, 2011). The distinctiveness and visibility (attractiveness) of celebrities are coming from the persona. Fournier and Herman (2004) argue that this persona is constructed through media stories and interpreted and reacted to by audiences. Parmentier (2011) eloquently describes the intersection of these concepts that could serve as the theoretical concept of a celebrity family. A strong brand has distinctive meanings and familiarity to the target market which is achieved by the co-creation process and communication efforts. On the other hand, Celebrities have distinctive personae and visibility from their audience which is achieved by their achievements, media interpretations, and media coverage. This concept can be implemented from the family business science standpoint, as there has been a significant number of family business literature that describes the benefit of being known to be a family business (Beck \& Kenning, 2015; Craig, Dibrell, \& Davis, 2008; Parmentier, 2011).

The presence of the family and its value can be considered as a distinct brand identity of a family business (Craig et al., 2008; Micelotta \& Raynard, 2011). The family brand identity is a 'message' that being delivered to the consumer's mind and being transformed into an image in the consumer's memory (Keller, 2003). Thus it is essential to preserve the reputation of the family business to avoid negative association towards the firm's brand identity which would affect the image in the consumer's mind. Reputation is among the top contributors to the perceived quality of the products that carry the brand name (Veloutsou \& Moutinho, 2009). Consumers expect that products manufactured today possess the same quality as products manufactured in the past (Milewicz \& Herbig, 1994). Therefore, if the family business brand could not deliver its promise, the reputation of the business 
would be damaged and consumers would be associated firm's brand identity negatively.

Preserving the reputation of a brand also essential in the context of the human brand. Rindova, Pollock, and Hayward (2006) define the human brand as any famous persona who becomes the subject of marketing communication. Celebrities could be considered as human brands since their performances on-stage and off-stage, online and offline, public or private is marketing and branding exercises (Centeno $\&$ Wang, 2017). Their reputation as a public figure should be preserved very well to avoid negative publicity as a result of their misconduct. Tarnished celebrities would inflict major negative reactions from consumers toward any entities associated with them including the celebrity-endorsed products (Zhou \& Whitla, 2013).

The combination of celebrity endorsement and family business branding strategy elements would create a unique marketing strategy, namely the celebrity family branding. Parmentier (2011) has presented the celebrity family branding strategy in her well-researched study by examining the practice of David and Victoria Beckhams (The Beckhams) family brand. Nonetheless, further analysis needs to be taken to identify whether consumers are truly interested in the family brand or toward the individual celebrity instead. Hsu and McDonald (2002) present that consumers already possess a certain association toward an endorser even though the advertisement is presenting multiple endorsers. Moreover, Ilicic and Webster's (2011) finding also supported the aforementioned research in which strong consumer attachment exists between the consumer and single celebrity regardless of whether the celebrity is endorsing a single brand or multiple brands.

\subsection{Digital Marketing Through Instagram}

Nowadays, human interaction has changed significantly as a result of the rapid growth of a web-based platform that facilitates a new online social behavior (Tiago $\&$ Verissimo, 2014). These changes have pushed marketers to create a new digital marketing strategy to adapt to the situation. From the media marketing perspective, there has been a shift of paradigm from the classical approach of AIDMA (Attention, Interest, Desire, Memory, and Action) to the modern AISAS (Attention, Interest, Search, Action, and Share) which could describe the consumer behavior on the internet (Wei \& Lu, 2013). AISAS model describes the psychological processes behind consumer decisions to purchase a new product. The product will attract the consumer's attention at first, thus consumers would be interested. Unlike the AIDMA model, the next action undertakes by the consumer is to search the information on the internet and after obtaining sufficient information, the consumer will take an action to purchase the products or services. Lastly, the consumer will share their consumption experience with others on the internet. However, the AIDMA model is still relevant to a certain point thus both models could complement each other to explain consumer behavior in the realm of the web world (Wei \& Lu, 2013).

Social media users have increased significantly in the current era and the utilization of social media as a marketing platform has been widely used, in which social media users could advertise their products and services or publicize their evaluation 
of particular products or services (Chahal \& Rani, 2017; Chen, Ching, Tsai, \& Kuo, 2011). One of the popular social media platforms commonly used to advertise certain products or services is Instagram. Instagram is the fastest-growing online photo (and video) social media where users could share their images from their daily life with other users (Sheldon \& Bryant, 2016).

The features of Instagram is very powerful as a digital platform for any promotional effort. Users could advertise their product freely by creating an Instagram account for their product. After creating the account, users could begin to market their product by using the most powerful feature of this application, which is photos and video sharing (Jin \& Ryu, 2020). Users may publish the advertisement of their products by posting tailor-made photos and videos for promotional purposes (Djafarova \& Bowes, 2020). Users also may 'tag' certain users when they publish the picture and video to notify them that a new advertisement has been posted. The second most important feature of this application is called 'caption'. A caption is an explanation that describes the information about images and videos which posted by users. In this caption, users may provide the written description or explanation of their product as well as utilize the third most important feature of this application; 'hashtags'(Jin \& Ryu, 2020). 'Hashtags' are tags or words which begin with '\#'. This notation is used to indicate the content of the picture or video which allows users to search for pictures and increase visibility (Giannoulakis \& Tsapatsoulis, 2016).

\subsection{Celebrity Family Brand and Instagram Marketing in Indonesia}

The number of Instagram users in Indonesia has reached a staggering number of 45 million active users per month and accounted for over 6 percent of all Instagram users in the world (Yosephine, 2017). The utilization of Instagram as an advertisement tool also has been very popular in Indonesia and the response from Indonesian users are also positive. According to polling in 2016, 56.2\% of Instagram users in Indonesia ages 18 to 35 follow digital retailers on the platform with the majority following clothing retailers (eMarketer, 2016). Thus, Indonesian Instagram users can be considered very familiar with Instagram advertisements. To cope with this new model of marketing competition, brands that advertise on Instagram need to have certain distinctiveness. Therefore, branding a product or service as a family business would be an advantage. In the context of family business branding in Instagram, the majority of brands that openly declare as a family business are owned by celebrities. They are confident enough to accentuate the family image in their brand due to their position as well-known public figures.

One of the Celebrity families which advertised their product by depicting family image extensively is Anang and Ashanty family or famously known as the Hermansyah. They are one of the most loved Indonesian celebrity couples. Anang Hermansyah is a famous music producer and singer in Indonesia. Previously he married Krisdayanti a well-known Indonesian diva. However, their marriage was ended, and eventually, Anang married Ashanty, a young and talented singer. 
Ashanty is regarded as a successful stepmother who could embrace Anang's children from the previous marriage. The Indonesian public is deeply sympathetic toward her and the couple rarely receive negative publicity. Besides a successful marriage, they have also established a successful business. They have launched numerous products to the market and interestingly they utilize Instagram as the main platform for promotion. Besides owning the business, they are also the endorser of their products. Both Anang and Ashanty (along with their children) are the advertisement models from all of their products on Instagram. Hence, analyzing the case of the Hermansyah family business advertisement would provide great insights about celebrity family business branding in the context of contemporary social media marketing.

\section{Research Methods}

The object of this study is Anang and Ashanty family business. They are a celebrity couple in Indonesia that has a good reputation and receive high publicity in Indonesian media (Mandagi and Lailiyah, 2016). Besides that, they have successfully established numerous product lines and a variety of brands, and, interestingly, both Anang and Ashanty (along with their children) are the advertisement models of all of their products on Instagram.

The research is divided into two separate studies. The first study is pre-experimental in nature. In the pre-experimental research, either a group or several dependent groups are observed for the effect of applying an independent variable that is presumed to cause change (Campbell \& Stanley, 1963). It is the basic method of design for experimental testing and is handled without any control group (Salkind, 2010). The method is chosen for the sake of practicability due to it is very difficult to conduct a true-experimental design as the study will focus on the response of The Hermansyah's Instagram followers that participate truly on a voluntary basis with the minimum possibility to contact them later on or burden them with long and multiple types of questionnaire. Based on the aforementioned premise, the research would use One-Group Post-tests-Only Design or a one-shot case study. In this research sub-design, all participants are assigned in a non-randomly manner as the intervention group (Salkind, 2010). This group of participants will later be presented with an intervention (in this case is the Instagram advertisements) and after that, the outcome is measured as a post-test.

The main purpose of the one-shot case study is to compare the Instagram user's response toward two types of Instagram advertisements. The first type of advertisement is depicting a single celebrity as the advertisement model and the second type is depicting a celebrity family as the model. The result of this experiment would reveal whether the Instagram users are favoring a single celebrity endorser or celebrity family endorser. The experiment would use a 2 x 2 factorial design to compare the Instagram user's response towards four stimuli of Instagram advertisements. After consulting with the corporate brand manager of the couple's company, the Author is permitted to publish the original advertisement from their product lines as stimuli. 


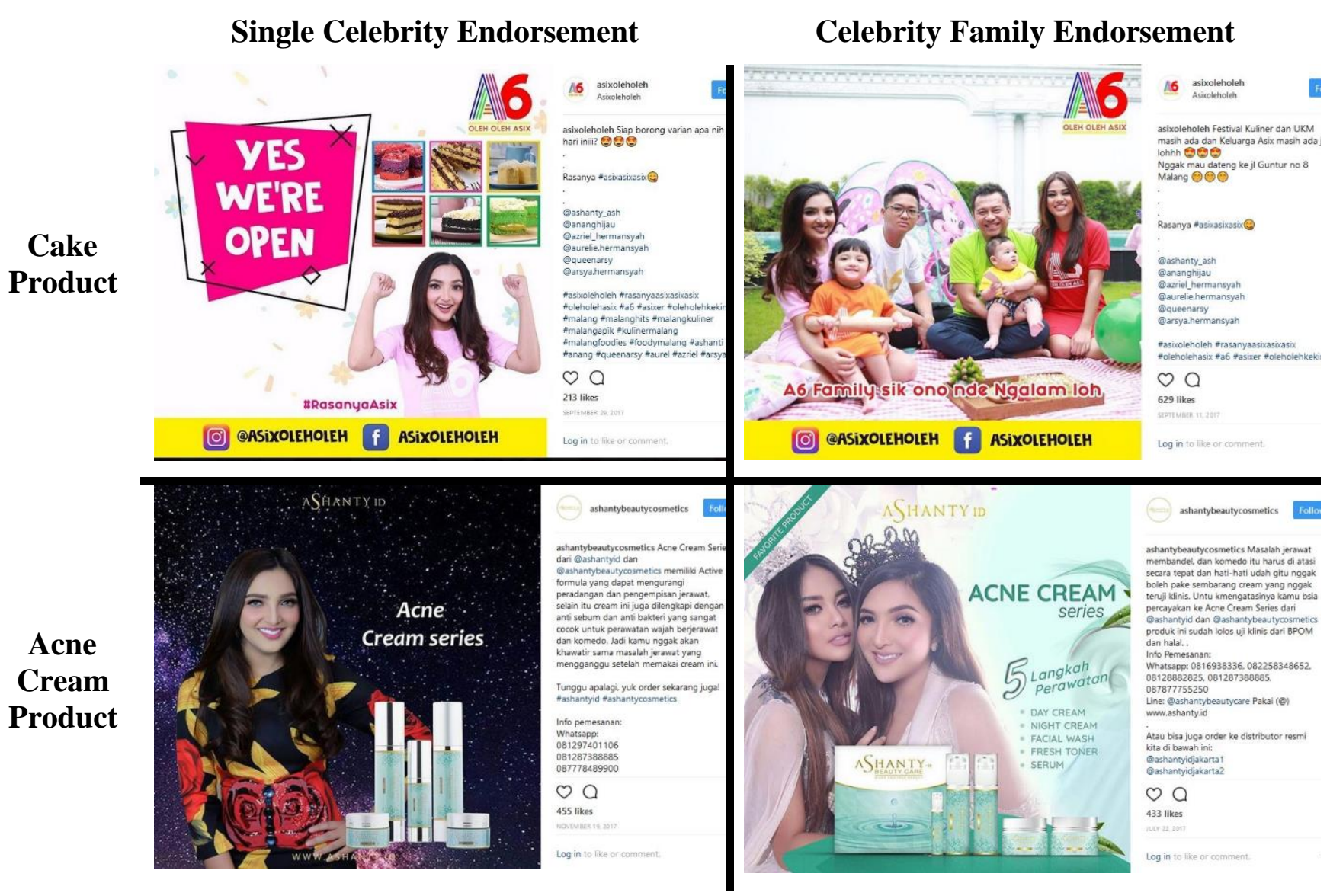

Figure 1 - The study 2 x 2 factorial design and its stimuli

As depicted in Figure 1, there are two types of products that are used as stimuli namely Oleh-Oleh Asix (cake product) and Ashanty ID (acne cream). Two stimuli would depict the Instagram advertisement of a single celebrity endorser (represents by Ashanty) and the other two stimuli would depict Instagram advertisement of celebrity family endorser (represents by Anang and Ashanty family). Based on each advertisement stimulus, the respondent would be asked to answer a series of questions with five points Likert scale response (strongly disagree, disagree, neutral, agree, and strongly agree). The measurement instruments of the first survey would adapt Wei and Lu (2013) research. Wei and Lu (2013) measurement instruments are selected due to their research framework, which combines the AIDMA and AISAS model, which is relevant to measure the behavior of social media users. Based on these models, the measurement instruments in this survey are comprised of seven composite variables namely attention, interest, desire, memory, search, action, and share.

The cake product is represented by the Oleh-Oleh Asix brand. Oleh-Oleh Asix is a cake brand exclusively distributed in Malang, a popular tourist destination in East Java Province. On the other hand, the cosmetics product is represented by Ashanty ID. Due to the product types of this brand are numerous, acne cream product is selected as the stimulus since the sales volume of this product is tremendous and the product could also be used by the male consumer. Both products are distinctly advertised by depicting celebrity family-themed advertisements and also by single celebrity-themed advertisements. The number of their followers are huge. It is 
recorded that Oleh-Oleh Asix has 79,000 followers while Ashanty ID has reached a staggering number of 170,000 followers.

The second survey is the consumer's opinion survey which measures respondent's opinion towards the advertisements. In this survey, the respondent would be asked to respond whether the information depicted in the advertisement for all of the four stimuli are sufficient or not. If their response is 'not sufficient', the respondents are required to state their reason. Besides that, respondents also require to answer whether the overall promotional effort on both products on Instagram is attractive or not. If their response is 'not attractive', the respondents are required to state their reason. Lastly, respondents are required to provide a suggestion about the overall promotional effort both for Oleh-Oleh Asix and Ashanty ID.

Participants of both studies are the Indonesian Instagram user which familiar with Anang and Ashanty products hence, non-probability sampling technique of convenience sampling are selected as the main sampling method due to there are a huge number of Instagram users who familiar with the couple's products. The questionnaire was created digitally by using 'Google forms', an online survey builder application. The questionnaire was then digitally distributed through Instagram's 'Direct Message' feature and Whatsapp messenger to 900 The Hermansyah's Instagram followers from January 3rd, 2018 to January 4th, 2018. The response rate from both surveys could be considered as very good in which 573 questionnaires were returned completely and after eliminating incomplete questionnaires, there were 547 questionnaires which considered as valid from both surveys. The total responses from the first survey are 254. From which the responses for the single celebrity endorser of cake product stimulus is 65 and the celebrity family endorser of cake product stimulus is 64 . On the other hand, the responses for the single celebrity endorser of acne cream product stimulus is 62 and the celebrity family endorser of acne cream product stimulus is 63 . The response rate of the second survey is greater than the first survey. The total number of participants of the second survey is 293 respondents.

\section{Results and Discussion}

This section would discuss research findings based on the two separate surveys which include sample characteristics as well as analysis and findings.

\subsection{The First Survey}

\subsubsection{Sample Characteristics}

The respondent's profile of the first survey is divided into age, education, occupation, and gender category. As depicted in Table 1, the majority of the respondents are young University educated females who work professionally as corporate employees. According to the generation theory, the majority of the respondents are categorized as the millennials generation. They are the tech-savvy generation who often spend their time on social media sharing their daily moments. Besides that, due to their familiarity with the internet, they often purchase products via a digital platform such as an online shopping website and even social media shopping. Thus, the sample in this study could be considered relevant to the research agenda in investigating Instagram user's attitudes. 
Table 1 - Respondent's Profile

\begin{tabular}{llll}
\hline Age & Number $(\%)$ & Education & Number $(\%)$ \\
\hline 17 to 21 years old & $38(15 \%)$ & High School & $53(21 \%)$ \\
22 to 26 years old & $105(41 \%)$ & Diploma/College & $18(7 \%)$ \\
27 to 31 years old & $64(25 \%)$ & Bachelor & $137(54 \%)$ \\
32 to 36 years old & $26(10 \%)$ & Higher than & $46(18 \%)$ \\
& & Bachelor & \\
37 to 41 years old & $14(6 \%)$ & & \\
42 to 46 years old & $3(1 \%)$ & & Frequency $(\%)$ \\
52 to 56 years old & $4(2 \%)$ & & $99(61 \%)$ \\
\hline Occupation & Number $(\%)$ & Gender & $155(39 \%)$ \\
\hline Corporate Employee & $94(37 \%)$ & Male & \\
Student & $73(29 \%)$ & Female & \\
Entrepreneur & $35(14 \%)$ & & \\
Civil Servant & $17(7 \%)$ & & \\
Housewife & $15(6 \%)$ & & \\
Teacher & $12(5 \%)$ & & \\
Other & $8(3 \%)$ & & \\
\hline
\end{tabular}

\subsubsection{Analysis and Findings}

As mentioned in the earlier section, the main objective of this study is to investigate the Indonesian Instagram user's perception of single celebrity endorsement and celebrity family endorsement. Therefore a proper statistical analysis is needed to be done to test whether the Instagram users are more favoring celebrity family advertisements than single celebrity advertisements based on conducted survey. The survey adopts Wei and Lu (2013) measurement instruments to identify consumer responses based on the aforementioned stimuli. According to the research design, respondents are classified into four groups. The first group is responding to the single celebrity advertisement for the cake product while the second group is responding to the celebrity family advertisement of the cake product. On the other hand, the third group is responding to the single celebrity advertisement of the acne cream and the fourth group is responding to the celebrity family advertisement of the acne cream. To observe the differences between previously mentioned groups, the Mann-Whitney $U$ test $(\alpha<0.05)$ is selected as the primary statistical analysis tool to compare the four stimuli. The use of the nonparametric test in this experiment is acceptable due to the nature of this research is exploratory (Salkind, 2010).

\subsubsection{Single Celebrity Cake Advertisement vs. Celebrity Family Cake Advertisement}

As depicted in Table 2, the advertisement featuring a single celebrity endorser is having a slightly more favorable impact than the celebrity family advertisement. 
The single celebrity-endorsed cake advertisement is significantly higher in terms of respondent's attention. On the other hand, the celebrity family endorsed cake is significantly higher in terms of respondent's desire.

Table 2 - Mann-Whitney $U$ test result

\begin{tabular}{lllll}
\hline Stage & $\begin{array}{l}\text { Single Endorser } \\
(\mathrm{N}=65) \\
\text { Mean rank }\end{array}$ & $\begin{array}{l}\text { Family Endorser } \\
(\mathrm{N}=64) \\
\text { Mean rank }\end{array}$ & Z score & $\mathrm{p}$ \\
\hline Attention & 93.55 & 36.00 & -9.524 & 0.000 \\
Interest & 65.92 & 64.7 & -0.285 & 0.776 \\
Desire & 58.49 & 71.61 & -2.020 & 0.043 \\
Memory & 70.18 & 59.73 & -1.614 & 0.106 \\
Search & 69 & 60.94 & -1.245 & 0.213 \\
Action & 59.82 & 70.27 & -1.619 & 0.105 \\
Share & 64.35 & 65.66 & -0.202 & 0.840 \\
\hline
\end{tabular}

Source: Author's calculation based on the conducted research in January 2018.

As can be seen in Table 2, the "attention" and "desire" $\alpha$ are less than 0.05 with a higher mean score for a single endorser in the "attention" and a higher mean score for family endorser in "desire". Based on the previously mentioned finding, it can be concluded that the single celebrity advertisement has captivated the attention of the respondents very well, however, in terms of stimulating consumer desire, the celebrity family advertisement is the champion. Thus, in the context of the cake advertisement, the celebrity family advertisement is able to stimulate consumer desire to think that they need the product as well as stimulate the desire to own the product. However, in terms of capturing consumer's attention and attracting consumers, the single celebrity advertisement is proven better

\subsubsection{Single Celebrity Acne Cream Advertisement vs. Celebrity Family Acne Cream Advertisement}

In contrast with the previous finding, the celebrity family acne cream advertisement produced a consistently more favorable impact than the single celebrity endorser advertisement as depicted in Table 3. As can be seen in Table 3, the "attention" and "search" $\alpha$ are less than 0.05 with a higher mean score for family endorser in the "attention" and a higher mean score for family endorser in "search". The celebrity family endorsed acne cream is significantly higher in terms of respondent's attention and search. Thus, in the context of acne cream advertisement, the celebrity family advertisement is prevailing in terms of capturing consumer's attention and attracting consumers. More importantly, the advertisement has stimulated respondents to search the product on the internet including its online word-of-mouth. 
Table 3 - Mann-Whitney $U$ test result

\begin{tabular}{lllll}
\hline Stage & $\begin{array}{l}\text { Single Endorser } \\
(\mathrm{N}=62) \\
\text { Mean rank }\end{array}$ & $\begin{array}{l}\text { Family Endorser } \\
(\mathrm{N}=63) \\
\text { Mean rank }\end{array}$ & Z score & $\mathrm{p}$ \\
\hline Attention & 35.06 & 90.50 & -9.950 & 0.000 \\
Interest & 57.44 & 68.47 & -1.737 & 0.082 \\
Desire & 59.47 & 66.48 & -1.106 & 0.269 \\
Memory & 58.04 & 67.88 & -1.561 & 0.118 \\
Search & 56.47 & 69.43 & -2.036 & 0.042 \\
Action & 57.71 & 68.21 & -1.646 & 0.100 \\
Share & 57.00 & 68.90 & -1.878 & 0.060 \\
\hline
\end{tabular}

Source: Author's calculation based on the conducted research in January 2018.

As can be seen in Table 2, the "attention" and "desire" $\alpha$ are less than 0.05 with a higher mean score for a single endorser in the "attention" and a higher mean score for family endorser in "desire". Based on the previously mentioned finding, it can be concluded that the single celebrity advertisement has captivated the attention of the respondents very well, however, in terms of stimulating consumer desire, the celebrity family advertisement is the champion. Thus, in the context of the cake advertisement, the celebrity family advertisement is able to stimulate consumer desire to think that they need the product as well as stimulate the desire to own the product. However, in terms of capturing consumer's attention and attracting consumers, the single celebrity advertisement is proven better.

\subsubsection{Single Celebrity Cake Advertisement vs. Single Celebrity Acne Cream Advertisement}

Further analysis of product comparison may be beneficial to test which product advertisements that favored more by the consumer in the context of a single celebrity endorser or celebrity family endorser. As depicted in Table 4, the "attention", "interest", "memory", "search", and "share" $\alpha$ are less than 0.05 with a higher mean score for family endorser in all items. Hence, it can be concluded that the single celebrity cake advertisement produced a consistently more favorable impact than the single celebrity acne cream advertisement. 
Table 4 - Mann-Whitney U test result

\begin{tabular}{|c|c|c|c|c|}
\hline Stage & $\begin{array}{l}\text { Single Endorser } \\
(\mathrm{N}=62) \\
\text { Mean rank }\end{array}$ & $\begin{array}{l}\text { Family Endorser } \\
(\mathrm{N}=63) \\
\text { Mean rank }\end{array}$ & Z score & $\mathrm{p}$ \\
\hline Attention & 70.46 & 57.23 & -2.256 & 0.024 \\
\hline Interest & 73.67 & 53.86 & -3.082 & 0.002 \\
\hline Desire & 66.62 & 61.26 & -0.838 & 0.402 \\
\hline Memory & 75.32 & 52.14 & -3.610 & 0.000 \\
\hline Search & 75.45 & 51.99 & -3.642 & 0.000 \\
\hline Action & 66.81 & 61.71 & -0.698 & 0.485 \\
\hline Share & 71.58 & 56.05 & -2.415 & 0.016 \\
\hline
\end{tabular}

Source: Author's calculation based on the conducted research in January 2018.

The difference between both groups is also significantly high in terms of attention, interest memory, search, and even action. Hence, it can be concluded that from the consumer point of view the single celebrity cake advertisement is proven better than the acne cream advertisement in attracting the consumer.

\subsubsection{Celebrity Family Cake Advertisement vs. Celebrity Family Acne Cream Advertisement}

Table 5 depicts the last analysis in this survey, in which the celebrity family cake advertisement prevails (in terms of the mean rank value) over acne cream advertisement except for "attention". Although almost all of the cake advertisement mean rank value is higher, in turn, their mean rank values are insignificant. Interestingly, the attention stage of acne cream advertisement is significantly higher than the cake. Therefore, it can be concluded that the celebrity family acne cream advertisement is more attractive to the consumer than the celebrity family cake advertisement in terms of "attention".

Table 5 - Mann-Whitney $U$ test result

\begin{tabular}{lllll}
\hline Stage & $\begin{array}{l}\text { Family Endorser } \\
\text { Cake (N=64) } \\
\text { Mean rank }\end{array}$ & $\begin{array}{l}\text { Family } \\
\text { Endorser Acne } \\
\text { Cream (N=63) } \\
\text { Mean rank }\end{array}$ & Z score & $\mathrm{p}$ \\
\hline Attention & 32.50 & 96.00 & -11.225 & 0.000 \\
Interest & 66.70 & 61.26 & -0.844 & 0.399 \\
Desire & 68.66 & 59.27 & -1.457 & 0.145 \\
Memory & 64.84 & 63.15 & -0.264 & 0.791 \\
Search & 65.02 & 62.96 & -0.321 & 0.748 \\
Action & 64.66 & 63.33 & -0.209 & 0.835 \\
Share & 65.13 & 62.85 & -0.359 & 0.720 \\
\hline
\end{tabular}

Source: Author's calculation based on the conducted research in January 2018. 


\subsection{The Second Survey (Consumer Voice)}

\subsubsection{Sample Characteristics}

As mentioned in the earlier section, the main purpose of the second survey is to capture consumer general opinion toward the stimuli and overall Instagram promotional effort. The participation rate of the second survey is greater than the first survey in which there are 293 respondents who participated in this 'consumer voice' survey. The respondent's profile of the first survey is divided into age, education, occupation, and gender category. As depicted in Table 6, the general characteristics of the second survey are similar to the first survey in which the majority of the respondents are young University educated female millennials who work professionally as corporate employees. Thus, the sample in this study could be considered relevant in capturing the opinion of this tech-savvy generation.

Table 6 - Respondent's Profile

\begin{tabular}{llll}
\hline Age & Number $(\%)$ & Education & Number $(\%)$ \\
\hline 17 to 21 years old & $39(13 \%)$ & High School & $59(20 \%)$ \\
22 to 26 years old & $124(42 \%)$ & Diploma/College & $30(10 \%)$ \\
27 to 31 years old & $80(27 \%)$ & Bachelor & $175(60 \%)$ \\
32 to 36 years old & $26(9 \%)$ & Higher than & $30(10 \%)$ \\
37 to 41 years old & $14(5 \%)$ & Bachelor & \\
42 to 46 years old & $5(2 \%)$ & & \\
52 to 56 years old & $6(2 \%)$ & & $112(38 \%)$ \\
\hline Occupation & Number $(\%)$ & Gender & \\
\hline Corporate Employee & $117(40 \%)$ & Male & \\
Student & $75(26 \%)$ & Female & \\
Entrepreneur & $40(14 \%)$ & & \\
Civil Servant & $22(7 \%)$ & & \\
Housewife & $14(5 \%)$ & & \\
Teacher & $15(5 \%)$ & & \\
Other & $11(4 \%)$ & & \\
\hline
\end{tabular}

Source: Author's calculation based on the conducted research in January 2018.

\subsubsection{Analysis and Findings}

The second survey is different than the first survey due to the main purpose of the second survey is to capture consumer general opinion toward the stimuli and overall promotional effort on Instagram. The analysis would be divided into three parts which comprise of advertisement's information sufficiency, advertisement's attractiveness, and the opinion of overall promotional effort in Instagram. 


\subsubsection{Advertisement's Information Sufficiency}

\subsection{The First Stimulus (Single Celebrity Advertisement of Cake} Product)

The majority of respondents in this study perceive that the information provided in the first stimulus is sufficient. However, there is a significant number of respondents who perceive the information in the first advertisement is not sufficient due to the price information is absent and the product description is not clear (as depicted in Figure 2 and Figure 3).

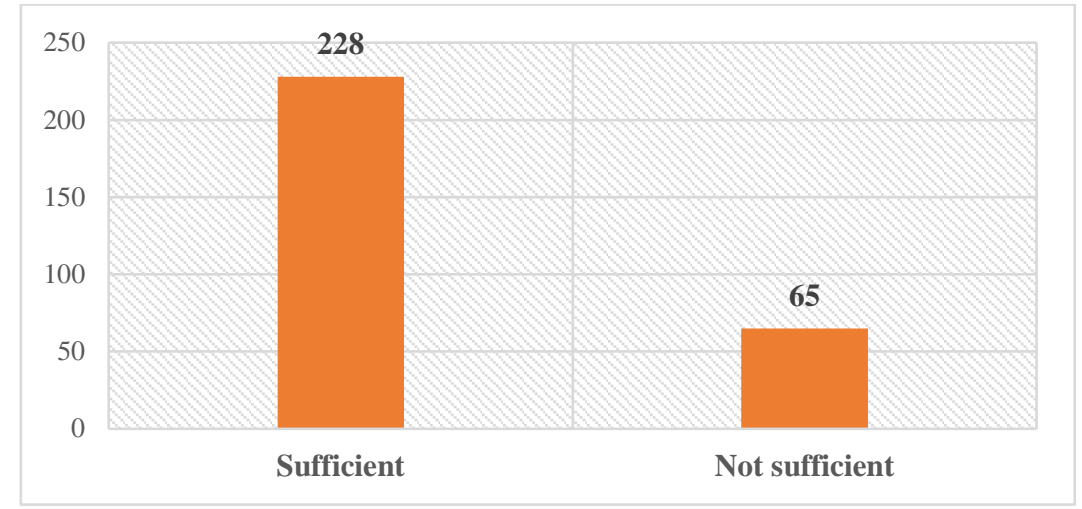

Figure 2 - Advertisement's Information Sufficiency of the First Stimulus

Source: Author's calculation based on the conducted research in January 2018.

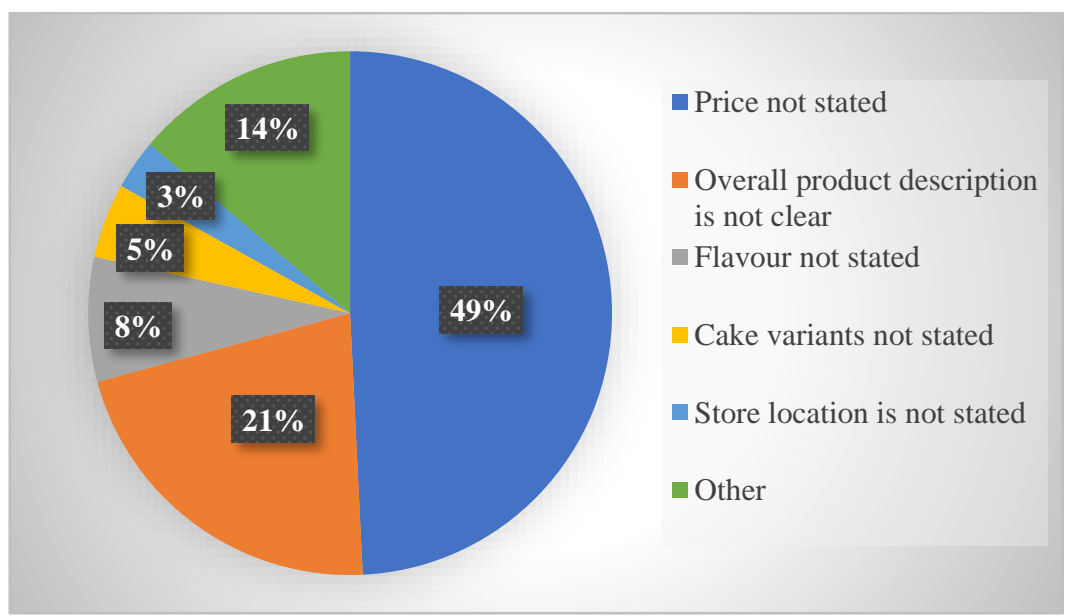

Figure 3 - Why The Information is Not Sufficient?

Source: Author's calculation based on the conducted research in January 2018.

\subsection{The Second Stimulus (Celebrity Family Advertisement of Cake Product)}

The majority of respondents in this study also perceive that the information provided in the second stimulus is sufficient and the number is slightly higher compared to the first stimulus. The main reason why some respondents argue that the information in the second stimulus is not sufficient is related to the absence of price information (as depicted in Figure 4 and Figure 5). 


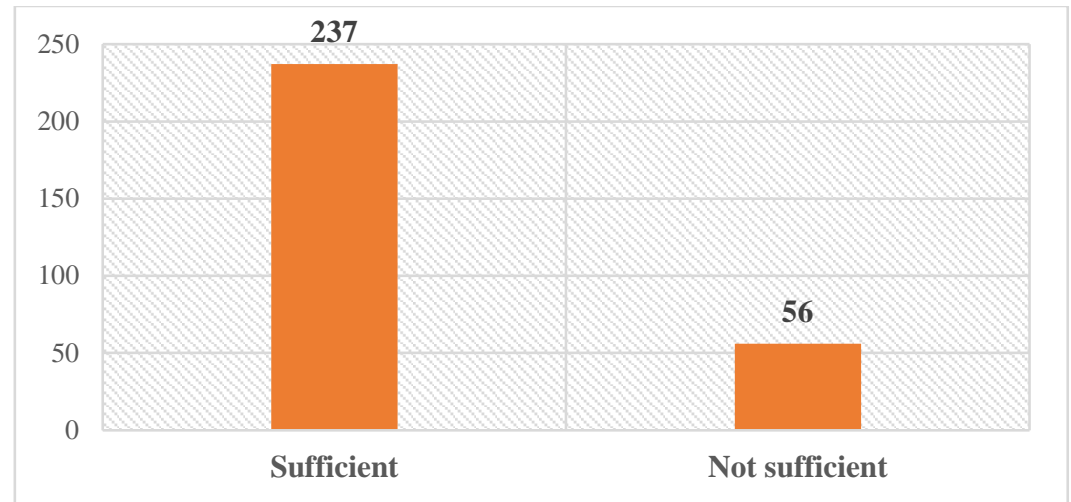

Figure 4 - Advertisement's Information Sufficiency of the Second Stimulus

Source: Author's calculation based on the conducted research in January 2018.

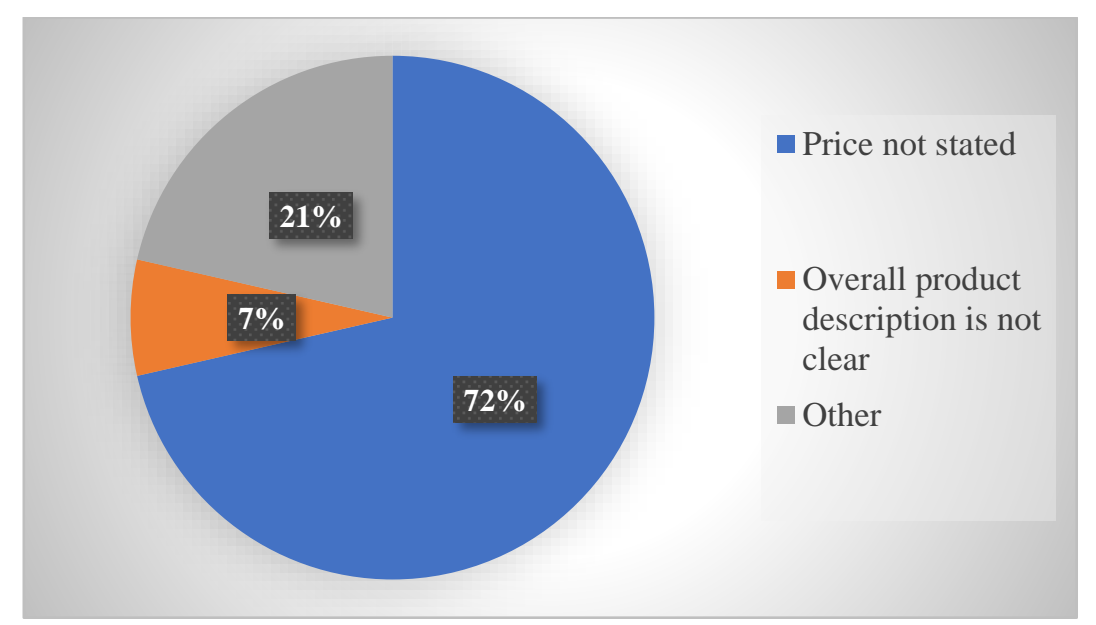

Figure 5 - Why The Information is Not Sufficient?

Source: Author's calculation based on the conducted research in January 2018.

\subsection{The Third Stimulus (Single Celebrity Advertisement of Acne Cream Product)}

Even though the product category in the third stimulus is different (acne cream), the majority of respondents in this study also perceive that the information provided in the advertisement is sufficient. The number of the respondent who stated that the number is not sufficient, surprisingly, lower than the previous two stimuli. The main reason why some respondents argue that the information in the third stimulus is not sufficient is related to the absence of information about cream types and price (as depicted in Figure 6 and Figure 7). 


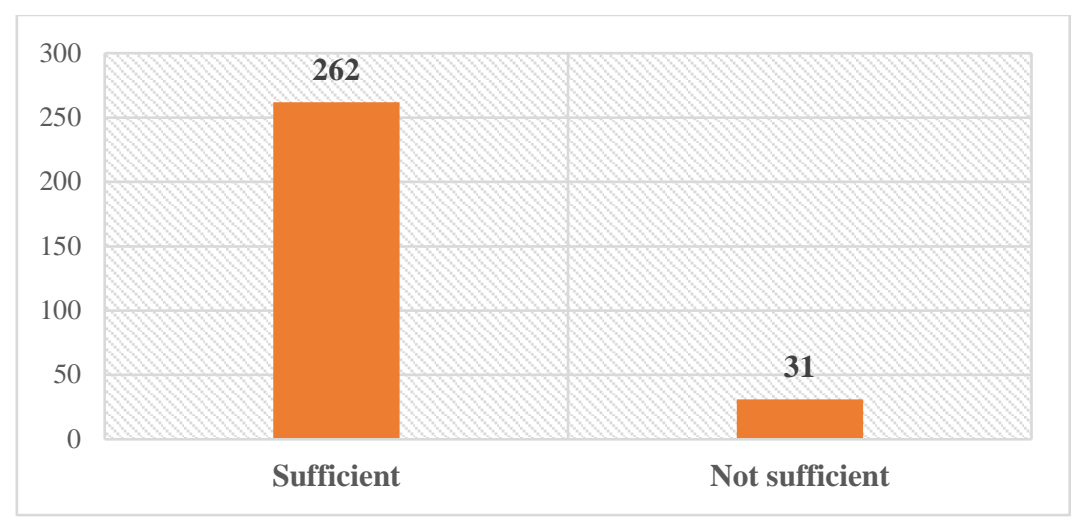

\section{Figure 6 - Advertisement's Information Sufficiency of the Third Stimulus}

Source: Author's calculation based on the conducted research in January 2018.

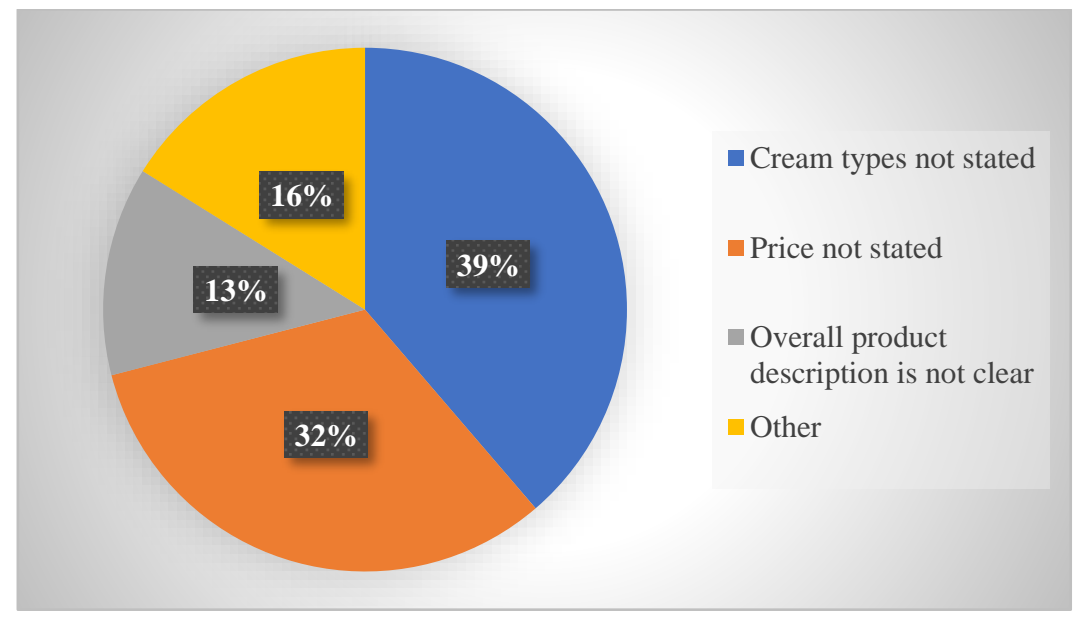

Figure 7 - Why The Information is Not Sufficient?

Source: Author's calculation based on the conducted research in January 2018

\subsection{The Fourth Stimulus (Celebrity Family Advertisement of Acne Cream Product)}

The majority of respondents in this study perceive that the information provided in the last advertisement is sufficient. The number of the respondent who stated that the information is not sufficient has decreased significantly compares to the three earlier stimuli. The main reason why some respondents argue that the information in the fourth stimulus is not sufficient is related to the absence of price information and, interestingly, some respondents need further explanation about product ingredients and their safety (as depicted in Figure 8 and Figure 9). 


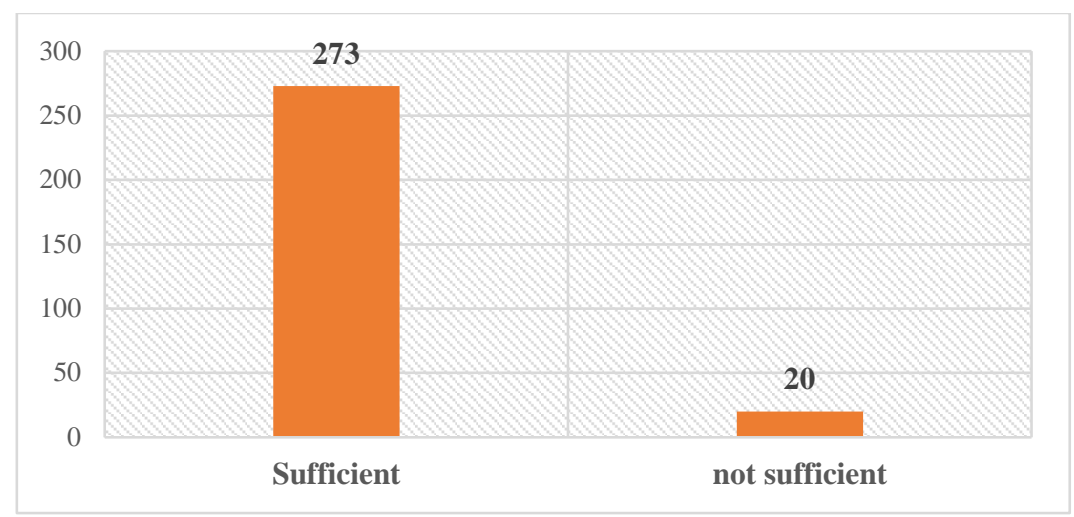

Figure 8 - Advertisement's Information Sufficiency of the Fourth Stimulus

Source: Author's calculation based on the conducted research in January 2018.

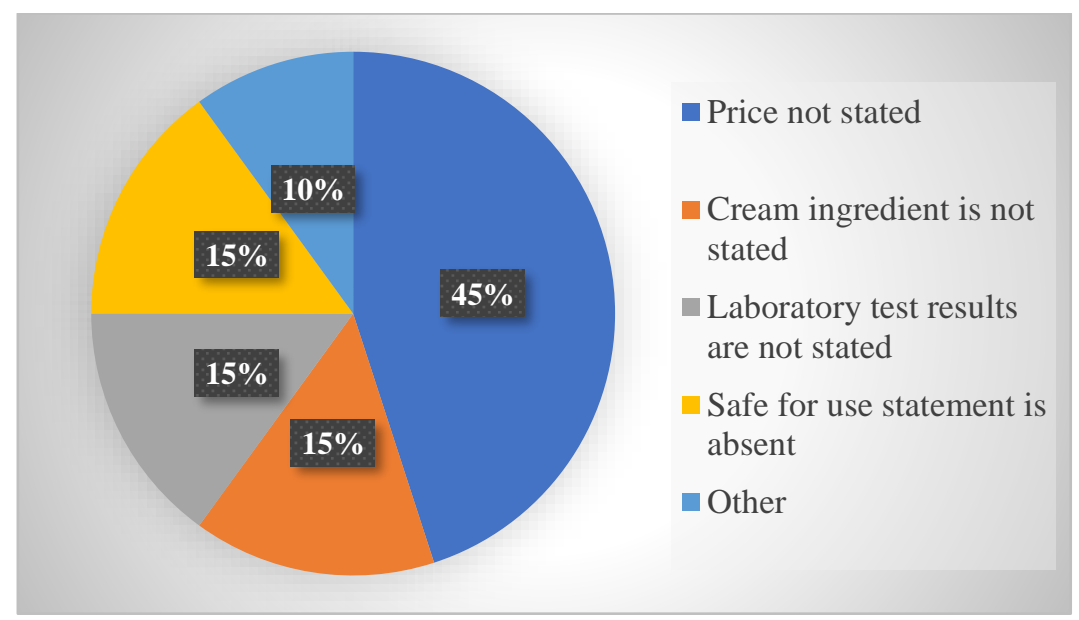

Figure 9 - Why The Information is Not Sufficient?

Source: Author's calculation based on the conducted research in January 2018

\subsubsection{Overall Advertisement's Attractiveness}

As depicted in Figure 10, the majority of the respondent perceives that all of the advertisements stimuli is attractive. However, there are several respondents who criticize the advertisements, and surprisingly their main reason is related to the unattractiveness of the Instagram content which makes the viewer bored. Besides that, there are also several respondents who argue that the advertisements rely on celebrity popularity rather than product quality (as depicted in Figure 11). 


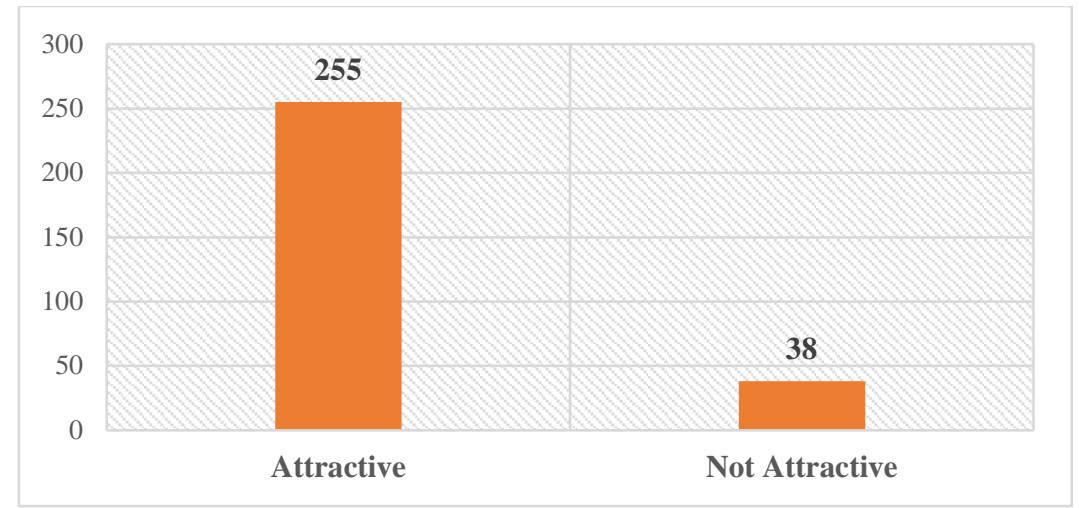

Figure 10 - Overall Advertisement's Attractiveness

Source: Author's calculation based on the conducted research in January 2018.

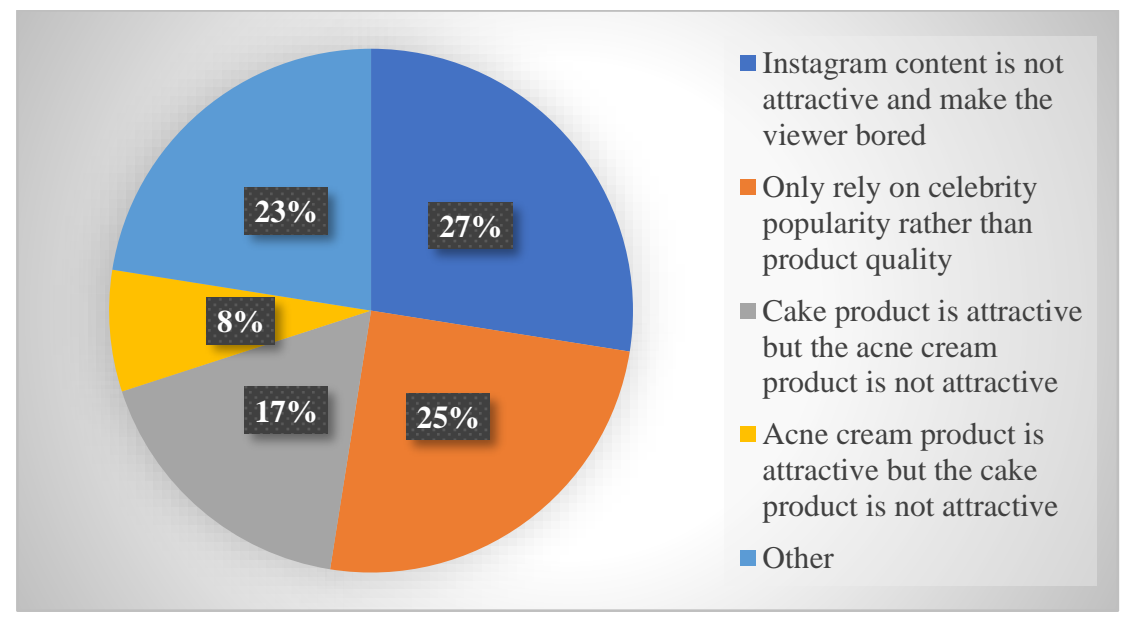

Figure 11 - Why The Advertisement is Not Attractive?

Source: Author's calculation based on the conducted research in January 2018.

\subsubsection{Overall Promotional Effort in the Instagram}

The overall promotional effort on Instagram is the last section of the second survey. In this section, respondents are encouraged to provide feedback about the overall promotional effort on Instagram. Due to the nature of this questionnaire section is voluntary, the response rate is lower than earlier. However, there are 109 pieces of valuable feedbacks from the respondents regarding the promotion of both products on Instagram. As can be seen in Table 7, the majority of the respondents state that the advertisements are lacking price information. Other concerns expressed by the respondents are related to the advertisements which overly focused on celebrity popularity rather than the product's quality and also respondent's request to create a better visual appearance. 
Table 7 - Respondent's Feedback

\begin{tabular}{ll}
\hline Feedback & Number (\%) \\
\hline $\begin{array}{l}\text { Please provide price information } \\
\text { All is fine }\end{array}$ & $26(24 \%)$ \\
$\begin{array}{l}\text { Please do not overly focused on celebrity popularity rather } \\
\text { than the product's quality }\end{array}$ & $12(11 \%)$ \\
$\begin{array}{l}\text { Please make better visual appearance } \\
\text { The advertisement is similar with other food and cosmetics }\end{array}$ & $11(10 \%)$ \\
$\begin{array}{l}\text { advertisement please make it more innovative } \\
\text { Please provide testimony and product review from other }\end{array}$ & $7(6 \%)$ \\
$\begin{array}{l}\text { Please provide the detail about product information } \\
\text { Please use other model for the advertisement (instead of } \\
\text { family members) to avoid bias }\end{array}$ & $6(6 \%)$ \\
$\begin{array}{l}\text { Please add more attractive content } \\
\text { Other }\end{array}$ & $6(6 \%)$ \\
\hline
\end{tabular}

Source: Author's calculation based on the conducted research in January 2018.

\section{Conclusion}

The finding from both surveys has provided abundant insights with regard to the celebrity family branding. The research has revealed that celebrity family endorsement for cake products could trigger the respondent's desire to purchase the product than a single celebrity endorsement. On the other hand, the celebrity family endorsement for acne cream product captivates respondent's attention as well as triggering the intention to search for more information about the product. Based on the two aforementioned main findings, it can be concluded that depicting celebrity family image in an advertisement may become an advantage in terms of capturing consumer attention, stimulating their desire to own the product, and encouraging the consumer to search the product information on the internet. However, a further promotional effort is needed to be taken due to the consumers are not taking any action to purchase the product after seeing the advertisement. Hence, the main research question of this study is finally answered. The consumer does value celebrity family endorsement more than individual or single celebrity endorsement but the engagement only exists in the initial stage (attention) and the middle stage (desire and search) of the consumer's psychological process to purchase a new product.

Further observation on the comparison between single advertisement of cake and acne cream product reveals that the consumer is favoring cake advertisement more than acne cream advertisement in terms of its attention, interest, memory, search, and share. On the other hand, the comparison between celebrity family advertisement of cake and acne cream product reveals that the acne cream advertisement prevails over cake advertisement and the advertisement has successfully captured consumer attention. The finding provides additional insights with regard to advertisement content on Instagram. The single celebrity 
advertisement in the first stimulus (cake) is the ideal example of a single product advertisement on Instagram. The advertisement has depicted essential content that could stimulate consumer's attention, interest, memory, search, and share. On the other hand, the celebrity family acne cream advertisement is the ideal example of family depiction on Instagram. It is found that the acne cream celebrity family advertisement has significantly captured consumer attention very well.

The reason why the depiction of celebrity family only engages the consumer in the initial and the middle stage of the consumer's psychological process may be revealed by the findings from the second survey. According to the second survey, although the information described in all advertisements are sufficient as well as the attractiveness level of all advertisements are high, all of the advertisement is lacking information about the price. This is the essential element of consumer consideration to purchase a new product. Without information about the price, there will be no action. The reason why the company does not present price information is related to their pricing strategy to avoid the price war with other competitors and they argue that if the consumer would like to know the price they could contact the company's hotline which is stated in the advertisement. In turn, the Indonesian consumer is reluctant to contact the hotline for asking the price list of the product.

Based on the author experience, the majority of Indonesian consumer is willing to contact the seller only if they have decided to purchase the product so that they contact the seller only to make an order or asking about the minor detail of the product. Hence, in the context of Instagram advertisement in Indonesia stating price is essential to stimulate consumer action to purchase the product. Besides price, in terms of the cosmetics products, the consumer is also has concerned about the safety of the product itself. They are asking whether the product has passed laboratory tests or not and whether the ingredients are safe to use. Since cosmetics products are related to consumer's well-being, information about product safety is essential to be included in the cosmetic advertisement.

The last important of this research is related to the respondent's opinion on a good Instagram advertisement. The respondent implies two important aspects of a good Instagram advertisement: First, the advertisement shall not rely on celebrity image itself but they must imply that the product has a good quality. Second, the content and visual appearances of the Instagram advertisement are the essential elements in attracting the consumer. Hence it can be concluded that to make a good Instagram advertisement, a product shall depict an equal portion of the image which represents the quality of the product and the image of the endorser.

This research has opened up an avenue for further exploration of celebrity family branding study in Indonesia. The research could serve as a stepping stone for further research of other Indonesian celebrity families that use true experimental design as the main limitation of this research is using pre-experimental design with a oneshot case study sub-design. The pre-experimental design was chosen to determine the value of celebrity family branding research in Indonesia before investing in a more comprehensive and immaculate true-experimental research design. As this research has shown promising findings, it is suggested to use a true-experimental research design for future research. 


\section{References}

Adi, A., \& Hidayat, A. (2018, December 14). Indonesia is Asia's Biggest Instagram Market with $45 \mathrm{mn}$ Users . Retrieved January 21, 2021, from https://en.tempo.co/read/894655/indonesia-is-asias-biggest-instagrammarket-with-45mn-users.

Aprilia, A., \& Setiadi, B. N. (2017). Online buying decision process among gen y instagram users. In International Conference on Psychology and Multiculturalism 2017 (pp. 68-73). Atma Jaya Catholic University of Indonesia.

Beck, S., \& Kenning, P. (2015). The influence of retailers' family firm image on new product acceptance: an empirical investigation in the German FMCG market. International Journal of Retail \& Distribution Management, 43, $1126-1143$.

Campbell, D., \& Stanley, J. (1963). Experimental and quasi-experimental designs for research. Chicago, IL: Rand McNally.

Centeno, D., \& Wang, J. J. (2017). Celebrities as human brands: An inquiry on stakeholder-actor co-creation of brand identities. Journal of Business Research, 74, 133-138.

Chahal, H., \& Rani, A. (2017). How trust moderates social media engagement and brand equity. Journal of Research in Interactive Marketing, 11(3), 312-335.

Chen, J. S., Ching, R., Tsai, H. T., \& Kuo, Y. J. (2008, June). Blog effects on brand attitude and purchase intention. In 2008 International Conference on Service Systems and Service Management (pp. 1-6). IEEE.

Craig, J. B., Dibrell, C., \& Davis, P. S. (2008). Leveraging family-based brand identity to enhance firm competitiveness and performance in family businesses. Journal of Small Business Management, 46(3), 351-371.

Diamond, N., Sherry Jr, J. F., Muñiz Jr, A. M., McGrath, M. A., Kozinets, R. V., \& Borghini, S. (2009). American Girl and the brand gestalt: Closing the loop on sociocultural branding research. Journal of Marketing, 73(3), 118134.

Djafarova, E., \& Bowes, T. (2020). 'Instagram made Me buy it': Generation Z impulse purchases in fashion industry. Journal of Retailing and Consumer Services, 102345.

eMarketer (2016). Instagram Users in Indonesia Follow Fashion; A majority of young adult Instagram users follow retailers. Retrieve February, 21, 2020 from https://www.emarketer.com/Article/Instagram-Users-IndonesiaFollow-Fashion/1013618.

Evans, D. (2010). Social media marketing: An hour a day. John Wiley \& Sons.

Fournier, S., \& Herman, K. (2004). Taking stock in Martha Stewart: insights into person-brand building and the cultural management of brands. Tuck School of Business Working Paper, 10. 
Giannoulakis, S., \& Tsapatsoulis, N. (2016). Evaluating the descriptive power of Instagram hashtags. Journal of Innovation in Digital Ecosystems, 3(2), 114129.

Holmes, S. \& Redmond, S. (2014). Socialising celebrity. Celebrity Studies, 5(3), 223-224.

Hsu, C. K., \& McDonald, D. (2002). An examination on multiple celebrity endorsers in advertising. Journal of Product \& Brand Management. 11,(1). 19-29.

Ilicic, J. \& Webster, C. M. (2011). Effects of multiple endorsements and consumercelebrity attachment on attitude and purchase intention. Australasian Marketing Journal, 19, 230-237.

Jin, S. V., \& Ryu, E. (2020). "I'll buy what she's\# wearing": The roles of envy toward and parasocial interaction with influencers in Instagram celebritybased brand endorsement and social commerce. Journal of Retailing and Consumer Services, 55, 102121.

Keller, K.L. (2003). Strategic Brand Management (2nd ed.). Prentice-Hall.

Kemp, S. (2020, February 18). Digital 2020: Indonesia - Data Reportal - Global Digital Insights. Retrieved January 21, 2021, from https://datareportal.com/reports/digital-2020indonesia\#: : :text=There $\% 20$ were $\% 20160.0 \% 20$ million $\% 20$ social,at $\% 205$ 9\%25\%20in\%20January\%202020.

Krappe, A., Goutas, L., \& von Schlippe, A. (2011). The "family business brand": An enquiry into the construction of the image of family businesses. Journal of Family Business Management, 1, 37-46.

Mandagi, N. N. \& Lailiyah, N. (2016). Audience Reception of Celebrity Private Sphere Through Janji Suci Raffi \& Gigi. Interaksi Online, 4(4).

Micelotta, E. R., \& Raynard, M. (2011). Concealing or revealing the family? Corporate brand identity strategies in family firms. Family Business Review, 24(3), 197-216.

Milewicz, J., \& Herbig, P. (1994). Evaluating the brand extension decision using a model of reputation building. Journal of Product \& Brand Management,3(1), 39-47.

Parmentier, M. A. (2011). When David met Victoria: Forging a strong family brand. Family Business Review, 24(3), 217-232.

Rindova, V. P., Pollock, T. G., \& Hayward, M. L. (2006). Celebrity firms: The social construction of market popularity. Academy of management review, 31(1), 50-71.

Rizal, V. Z. (2019). Komunikasi Pemasaran Media Sosial Instagram Pada Toko Kue Selebriti Bandung Makuta (@ Bandungmakuta) Terhadap Kesadaran Merek. Inter Komunika, 4(1), 75-87.

Salkind, N. J. (Ed.). (2010). Encyclopedia of research design (Vol. 1). Sage. 
Sheldon, P. \& Bryant, K. (2016) Instagram: Motives for its use and relationship to narcissism and contextual age. Computers in Human Behavior, 58, 89-97.

Sherry, J. F., Jr. (2005). Brand meaning. In A. M. Tybout \& T. Calkins (Eds.), Kellogg on branding (pp. 40-72). Hoboken, NJ: John Wiley.

Tandean, K. A. C. (2018). Personal Branding Selebgram Balita Tatan (@ Jrsugianto) Di Sosial Media Instagram. Agora, 6(2).

Thomson, M. (2006). Human Brands: Investigating Antecedents to Consumers' Strong Attachments to Celebrities. Journal of Marketing, 70, 104-119.

Tiago, M. T. P. M. B. \& Verissimo, J. M. C. (2014). Digital marketing and social media: Why bother? Business Horizons, 57, 703-708.

Utari, M. \& Rumyeni, R (2017). Pengaruh Media Sosial Instagram Akun @Princessyahrini Terhadap Gaya Hidup Hedonis Para Followersnya. Jurnal Online Mahasiswa Fakultas Ilmu Sosial dan Ilmu Politik Universitas Riau, 4, 2, 1-15.

Veloutsou, C. \& Moutinho, L. (2009). Brand Relationships through Brand Reputation and Brand Tribalism. Journal of Business Research, 62(3), 314322.

Verawati, N. (2016). Pergeseran Pemanfaatan Instagram sebagai Media Bisnis Online (Studi Kasus pada Akun@ Schonehazzle). KOM \& REALITAS SOSIAL, 12(12).

Wei, P. S. \& Lu, H. P. (2013) An examination of the celebrity endorsements and online customer reviews influence female consumers' shopping behavior. Computers in Human Behavior, 29, 193-201.

Yosephine, L. (2017, July 26). Indonesia Instagram's biggest market in Asia Pacific. Retrieved February 21, 2018, from https://www.thejakartapost.com/life/2017/07/26/indonesia-instagramsbiggest-market-in-asia-pacific.html

Zhou, L. \& Whitla, P. (2013). How negative celebrity publicity influences consumer attitudes: The mediating role of moral reputation. Journal of Business Research, 66, 1013-1020. 